\title{
STEM approach and computer science impact the metaphorical thinking of Indonesian students'
}

\section{El enfoque STEM y las ciencias de la computación impactan el pensamiento metafórico de los estudiantes indonesios}

\author{
Farida Farida \\ Universitas Islam Negeri Raden Intan Lampung, Bandar Lampung, Indonesia \\ farida@radenintan.ac.id \\ Nanang Supriadi \\ Universitas Islam Negeri Raden Intan Lampung, Bandar Lampung, Indonesia \\ nanangsupriadi@radenintan.ac.id \\ Siska Andriani \\ Universitas Islam Negeri Raden Intan Lampung, Bandar Lampung, Indonesia \\ siskaandriani@radenintan.ac.id \\ Dona Dinda Pratiwi \\ Universitas Islam Negeri Raden Intan Lampung, Bandar Lampung, Indonesia \\ donadindapratiwi@radenintan.ac.id \\ Suherman Suherman \\ University of Szeged, Szeged, Hungary \\ suherman@edu.u-szeged.hu \\ Rosida Rakhmawati Muhammad \\ Coventry University. Priory Street, UK \\ muhammadr@uni.coventry.ac.uk
}

\begin{abstract}
Metaphorical thinking is important in improving the formation and discovery of learning ideas in the 21st-century. However, the metaphorical thinking of Indonesian students is below the international average in terms of cognitive process, according to PISA 2018. This study aims to identify differences in the ability of students' metaphorical thinking in learning STEM and Computer Science (STEM-CS). This research employed the experimental design with a simple random sampling technique to determine the sample. The population of this study was 280 junior high school students in Bandar Lampung, Indonesia. The data collection technique has been tested to see the improvement of metaphorical thinking. Hypothetical testing has been used by one-way ANOVA with a meaningful level of 5\%. The results found that the average class value applied to the STEM-CS training model was 88.00, which was higher compared to the STEM class with an average score of 86.00 and the control class with an average score of 73.00. It is concluded that the STEM-CS model can be used as an alternative solution for learning in the industrial era 4.0.
\end{abstract}

Key words: computer science; metaphorical thinking; STEM.

\section{Resumen}

El pensamiento metafórico es importante para mejorar la formación y el descubrimiento de ideas de aprendizaje en el siglo XXI. Sin embargo, el pensamiento metafórico de los estudiantes indonesios está por debajo de la media internacional en términos de proceso cognitivo, según PISA 2018. Este estudio tiene como objetivo identificar las diferencias en la capacidad del pensamiento metafórico de los estudiantes en el aprendizaje de STEM y Ciencias de la Computación (STEMCS). Esta investigación empleó el diseño experimental con una técnica de muestreo 
aleatorio simple para determinar la muestra. La población de este estudio fue de 280 estudiantes de secundaria en Bandar Lampung, Indonesia. La técnica de recopilación de datos se ha probado para ver la mejora del pensamiento metafórico. Se han utilizado pruebas hipotéticas mediante ANOVA unidireccional con un nivel significativo del 5\%. Los resultados encontraron que el valor de clase promedio aplicado al modelo de entrenamiento STEM-CS fue 88,00, que fue mayor en comparación con la clase STEM con una puntuación media de 86,00 y la clase control con una puntuación media de 73,00. Se concluye que el modelo STEM-CS se puede utilizar como una solución alternativa para el aprendizaje en la era industrial 4.0.

Palabras clave: informática; pensamiento metafórico; STEM.

\section{Introduction}

The concept of thinking that emphasizes the relationship between mathematics and real-life phenomena in the 21st-century is metaphorical thinking (Chang \& Jonathan, 2019; İdin, 2019; Vlasis, 2019). Metaphorical thinking can provide insight into ideas to make logical conclusions that lead to new ideas (Abdurrahman, Setyaningsih, et al., 2019; Hendriana et al., 2018; Surya \& Putri, 2017). As a learner, it is important to find a good metaphorical thinking management strategy to produce good academic output related to the field of science (Dumitru, 2019; Jaccard \& Jacoby, 2019; Silvia \& Beaty, 2012; Tambunan, 2018; Wagiran et al., 2019). Metaphorical thinking emphasizes the formation to find technical ideas (Bobrova et al., 2020; de Barros et al., 2010; Saragih et al., 2016). Metaphorical thinking can provide a great opportunity for students to exploit their knowledge in learning mathematics (Cassel \& Vincent, 2011; Castek \& Beach, 2013; Leikin, 2020; Reeder et al., 2009; Supriadi et al., 2019). Also, they are provided an opportunity to explore their abilities (Hendriana et al., 2017, 2018; Setiani \& Waluya, 2018; Ulfah et al., 2017), critical aspect particularly relevant to the analysissynthesis component of the design process (McAuliffe, 2016; Rany et al., 2020; Suherman et al., 2020; Yasin et al., 2020), and to see the relationship between the knowledge they obtain and their daily lives (Featherstone, 2020; Gibbs Jr et al., 2004; Lakoff, 2014; Landau, 2016). The process of exploring this ability will arouse curiosity and reflect on the knowledge that has been built (Andari et al., 2020; Hartinah et al., 2019; Huda et al., 2019; Kashdan et al., 2018; Suherman et al., 2021).

However, Indonesian students' metaphorical thinking abilities are still far from good compared to the metaphorical thinking abilities of foreign students. This is evidenced by the percentage data comparison of metaphorical thinking of Indonesian students' and the overseas students in terms of the cognitive process in the areas PISA 2018. 


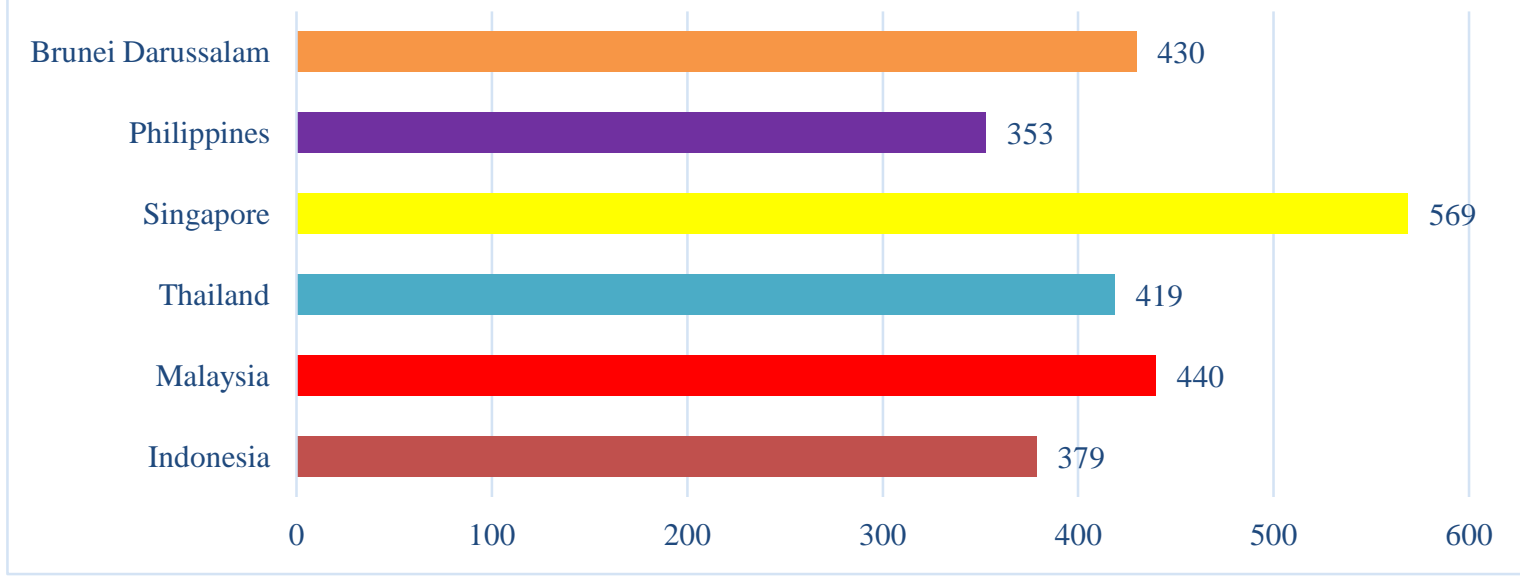

Figure 1. Graphic of Southeast Asian Nations Mathematics Ability

Graph 1 shows that Singapore is the country with the highest score of 569 and the Philippines is the country with the lowest score of 353. Indonesia only scored 379 that is below the international average of 489 . Based on this, it is suspected that the learning system has not been fully effective in building students' technical ideas.

The solution to overcome these problems and to foster the metaphorical thinking is to prepare educational provisions (Laurens et al., 2017). One of them is Science, Technique, Engineering, and Mathematics (STEM) learning (Greca Dufranc et al., 2020; Ibáñez \& Delgado-Kloos, 2018; Suherman, 2018). STEM is popular at the world level that is effective to be applied as integrative thematic learning (Barakabitze et al., 2019; Kang, 2019; Peterson \& Hipple, 2020). This learning combines four main areas in education, namely science, technology, mathematics, and engineering (Park et al., 2017; Stoet \& Geary, 2018). STEM is an important issue in current educational trends (Becker \& Park, 2011; Saxton et al., 2014; Yu et al., 2016) and is internationally recognized to be able to advance the skills needed by the 21st-century society (Drew, 2012; Helmi et al., 2019; Trilling \& Fadel, 2009).

STEM can be combined with computer science to provide students more comprehensive learning experience (Chung et al., 2014; Hernandez et al., 2014; Ortiz et al., 2015). Because we believe that STEM with computer science can provide opportunities to learn mathematical concepts (Barr \& Stephenson, 2011; Deitrick et al., 2015; Ritz \& Fan, 2015; Sengupta et al., 2013). Therefore, computer science can facilitate teaching and learning activities to be interesting and not monotonous (Meerbaum-Salant et al., 2013; Ruthven et al., 2004; Sari et al., 2016; Yin et al., 2007), so that teaching through the technological advances (Duarte \& Baranauskas, 2018; Vakil, 2018), the process of curriculum delivery and understanding of various disciplinary/interdisciplinary can be facilitated (Bell et al., 2017; Sagala et al., 2019; Woo et al., 2012).

Based on previous research, STEM can improve mathematical thinking ability (Dare et al., 2018; Hobbs et al., 2018; Huda et al., 2020; Sagala et al., 2019; Singh et al., 2018; Yasin et al., 2020), students can learn to be involved in the process of analyzing problem spaces, generating ideas, and developing a better understanding of the relationship between variables and thinking concepts (Goodway et al., 2019; Nilsen, 2020; Skovsmose, 2020), provide an increase in higher-order thinking (Hashim et al., 2017), and provide good techniques for teachers (Siew et al., 2015). STEM learning can 
improve literacy in science, mathematics, technology, and engineering (Tati et al., 2017), train causal reasoning (Fitriani et al., 2017), improve creative thinking skills (Ismayani, 2016; Mayasari et al., 2016; Meyrick, 2011), be useful in metaphorical learning (Çalisici \& Sümen, 2018; Pellas et al., 2017), can increase achievement and interest in learning (Canning et al., 2019; Syukri et al., 2013; Vongkulluksn et al., 2018), and increase motivation and provide experience in the engineering process (Borrego \& Henderson, 2014; Morgan et al., 2019; Suwarma et al., 2015). Furthermore, there is no research which is combining STEM and computer science (STEM-CS) using metaphorial thinking skill. Based on previous research, the novelty of this research lies in the integration of computer science in STEM learning to improve metaphorical thinking.

Thus, the purpose of this study is to compare the two learning models, namely STEM and STEM-CS learning towards students' metaphorical thinking. Through STEM-CS, students are expected to be motivated to explore and foster their love for learning. With the advancement of technology, STEM-CS will become the standard informing students' understanding, knowledge, skills, abilities, and learning processes.

\section{Method}

This research is quasi-experimental. The respondents in this study were 280 secondary school students in Bandar Lampung. The total number of 93 secondary school students sample was found. Of these, there were $48(51.61 \%)$ females and $45(48.39 \%)$ males. In order to determine the experiment class and the control class, the simple random sampling technique with no replacement method was used. It means that each element of the population has an equal opportunity to be elected as the members of the sample. Two of the classes were randomly selected as an experimental group and other for the control group. There were 32 students in the experimental group 1, 30 students in the experimental group 2, while 31 students in the control group. After selecting the control and experimental groups, the students were matched according to their first term mathematics scores (Suherman et al., 2020). The study was carried out for a total of 18 hours. During the process of preparing activities and post-test questions, Indonesia junior high school curriculum was considered and 3 activities were prepared. In the experimental group 1 dynamic oriented activity was used by using the STEM-CS learning model. In the experimental group 2 were used by using the STEM learning model. In the control group, the normal teaching sequence in the curriculum was followed.

The data analysis was used SPSS Version 25.0. The data collection technique used was an essay test to measure metaphorical thinking. The indicators of metaphorical thinking include (Hendriana, 2012): 


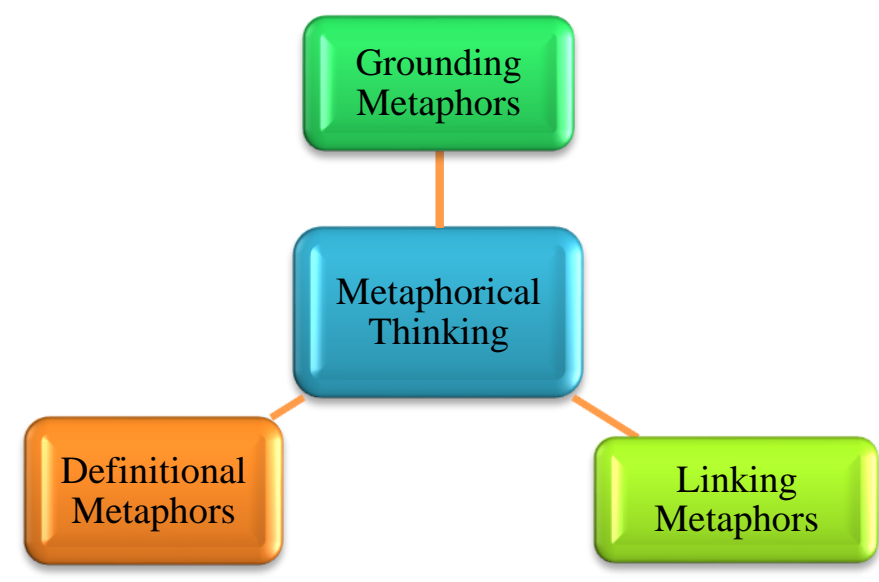

Figure 2. Metaphorical Thinking Indicators

The test was normal with Kolmogorov-Smirnov. The Kolmogorov-Smirnov test is used to test the null hypothesis that the data set comes from a result of pretest of metaphorical thinking. Furthermore, the Levene Statistic were used to see the homogenity. The STEMCS learning steps were carried out using the following steps:

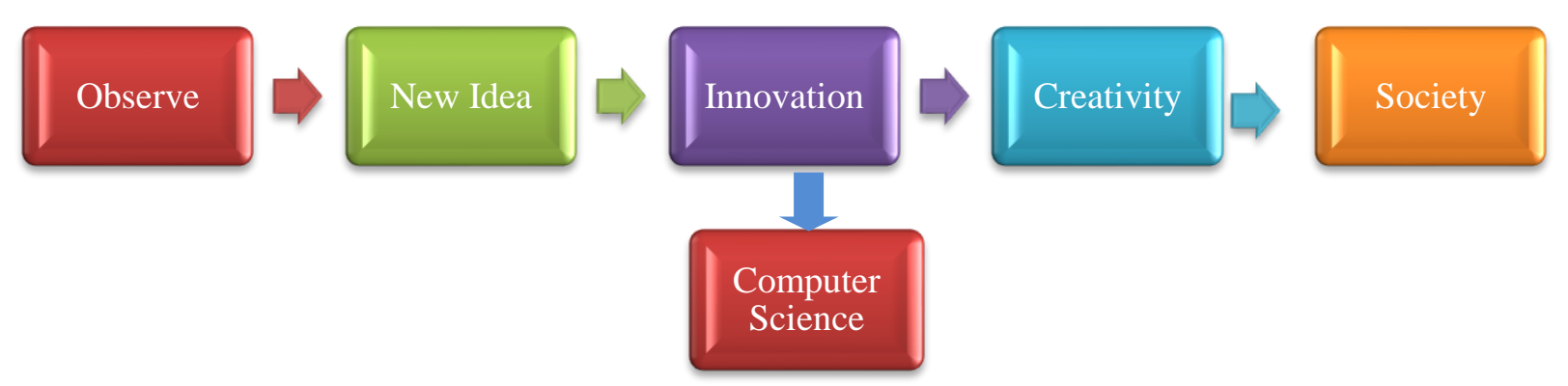

Figure 3. The STEM-CS Learning Steps

The prerequisite tests were conducted using the normality test with Kolmogorov Smirnov and Homogeneity test with Levene's Statistics used by SPSS Version 25.0. The hypothetical testing was performed using one-way ANOVA.

\section{Results}

Based on data analysis, the researchers combined the research data in the form of data on the metaphorical thinking abilities in the experimental class and the control class. The data collected were in the form of two test such as pretest and posttest, both the STEMCS, STEM, and control class. Based on the research design, descriptive test results for score data will be presented to measure metaphorical thinking skill in Table 1. 
Table 1.

Description of the Students Metaphorical Thinking Ability Score

\begin{tabular}{ccccccc}
\hline & Metaphorical Tingking Ability & Min & Max & Mean & St.Dev & Range \\
\hline \multirow{3}{*}{ Pretest } & Experiment 1 & 66.43 & 60.30 & 65.73 & 10.057 & 30.31 \\
& Experiment 2 & 56.90 & 50.50 & 55.48 & 7.748 & 29.72 \\
& Control & 55.48 & 40.00 & 54.54 & 10.12 & 24.00 \\
\hline \multirow{3}{*}{ Posttest } & Experiment 1 & 88.00 & 66.00 & 75.81 & 4.77 & 41.23 \\
& Experiment 2 & 86.00 & 64.00 & 72.00 & 4.92 & 31.22 \\
& Control & 73.00 & 54.00 & 68.78 & 5.23 & 26.92 \\
\hline
\end{tabular}

Based on Table 2, it can be seen that results of the pretest and posttest of each class were different. Overall, the category of metaphorical thinking data that pretest and posttest spent most on experiment 1 , experiment 2 , and control class. The lowest spending could be seen in the pretest in all descriptions data. The highest description data was posttest. In terms of pretest, the data maximum spent the most at 66.43 in experiment 1 . The data maximum of experiment 1 was also higher to about 88.00 compared to experiment 2 which spent the least (56.90) in pretest. On the other hand, the lowest data was on pretest which counted for 55.48. While the posttest data which is around 73.00. The following is the graphic of the pretest and posttest score on metaphorical thinking abilities:

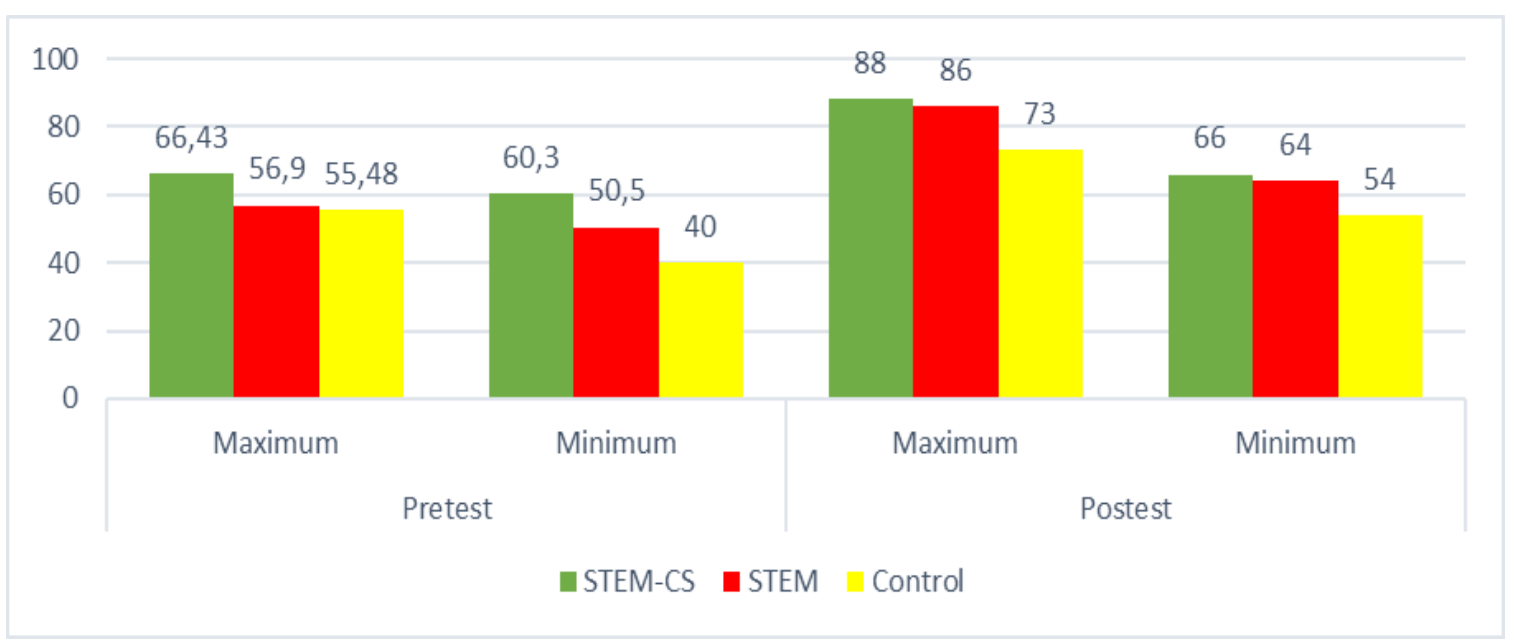

Figure 4. Graphic of Pretest and Posttest Scores on Metaphorical Thinking Abilities

The bar chart illustrates the results of the maximum and minimum scores in pretest and posttest in three different class, namely STEM-CS, STEM, and control class. Overall, the most popular metaphorical thinking over a significant increase in students' metaphorical thinking abilities after the implementation of STEM-CS in the experimental class 1, STEM model in the experimental class 2, and school's model in the control class. 
Table 2.

Normality Test Results

\begin{tabular}{llcccccc}
\hline \multirow{2}{*}{ Teaching Methods } & \multicolumn{3}{c}{ Kolmogorov-Smirnov ${ }^{\mathbf{3}}$} & \multicolumn{3}{c}{ Shapiro-Wilk } \\
\cline { 2 - 8 } Value & Statistic & df & Sig. & Statistic & df & Sig. \\
\cline { 2 - 8 } & STEM & .158 & 30 & .055 & .938 & 30 & .080 \\
& STEM-Computer Science & .141 & 32 & .109 & .967 & 32 & .430 \\
& Control & .143 & 31 & .082 & .926 & 31 & .209 \\
\hline
\end{tabular}

Based on the table 2, it can be seen the application of the STEM, STEM-CS, and control model with sig value was $0.055,0.109$, and 0.082 respectively, which means that the sample came from a normally distributed population with significant level of $\alpha=0.05$. Furthermore, it can be continued at the homogeneity ov variance test stage. The results data was presented in Table 3.

Table 3.

Variance Homogeneity Test Results

\section{Student learning outcomes}

\begin{tabular}{cccc} 
Levene Statistic & df $_{\mathbf{1}}$ & $\mathbf{d f}_{\mathbf{2}}$ & Sig. \\
\hline .619 & 5 & 56 & .686 \\
\hline
\end{tabular}

Levene's test of homogeneity of variance is used in SPSS version 25. The results in Table 3 , it is clear that metaphorical thinking data was normally distributed with significance level of 0.05 was obtained sig value of 0.686 highest than 0.05 . Going to the homogeneous variance, the data showed a variance homogeneity. It is known that the data can be continou using a one-way ANOVA test. The aim of the one-way ANOVA was to find the differences in the teaching model. The one-way ANOVA test results are followed:

Table 4.

Test Results of Hypotetical

\begin{tabular}{ccccccc}
\hline Variances & JK & Dk & RK & $F_{\text {observed }}$ & $F_{\text {critical }}$ & Result \\
\hline Model (A) & 13673.23 & 2 & 6886.74 & 59.03 & 3.15 & $H_{0}$ is rejected \\
Error (G) & 10233.72 & 61 & 116.67 & & & \\
Total (T) & 23707.21 & 63 & & & & \\
\hline
\end{tabular}

Based on Table 4, the results of the one-way ANOVA showed an increase in the numer of metaphorical thinnking abilities through the STEM-CS model. This shows that the use of STEM-CS is appropriate to improve students' metaphorical thinking abilities. On the other hand, the average metaphorical thinking score in STEM-CS model was higher than the STEM model and models. So, it can be concluded that the STEM-CS model is better than the STEM and normal teaching sequence in the curriculum was followed. 


\section{Discussion}

The results of this study are in accordance with the research hypothesis. The metaphorical thinking abilities is better because STEM-CS learning utilizes information technology or computer and internet for education and learning. The using of information technology, in this case, is the use of computers that show significant achievements (D'silva, 2007). The students can be guided to solve everyday problems by using technology and combining mathematical thinking patterns and techniques that will bring up new ideas.

STEM-CS learning can increase sensitivity to real-world problems and make students able to provide various answers or solutions with justification for various phenomena contained in the environment of everyday life related to metaphorical thinking abilities. STEM learning without Computer Science will make the process of finding information slower because of the limited resources to search for information. This has led to the improvement of metaphorical thinking abilities through STEM-CS learning better.

Based on the steps to improve metaphorical thinking through STEM-CS learning there are stages of forming ideas and creativity using computer science assistance, namely the analysis of the questions given by the teacher and the collection of facts from other students, then discuss to find solutions to the given problems. Metaphorical thinking in STEM learning can also be improved through the stage of forming new ideas, creativity without computer science. As an achievement of improving students' metaphorical thinking in learning STEM-CS refers more to the stage of the use of computer science which gives new experiences to students in learning.

STEM-CS learning is better in influencing students' metaphorical thinking than STEM learning and normal school curriculum learning. This is based on the STEM-CS learning steps. There is an approaching stage by giving new ideas, creativities, and innovations to students in accordance with the students' abilities, due to learning mathematics in class can provide optimal results (Abdurrahman, Nurulsari, et al., 2019; Canning et al., 2019; Morgan et al., 2019; Pradubthong et al., 2018; Trevallion, 2018; Vale et al., 2018; Vongkulluksn et al., 2018).

Judging by the differences in this step, it seems that the STEM-CS learn to provide intensive care for students to the effect of improving the metaphorical thinking of students, where students can apply new ideas and find various solutions for a problem.

\section{Conclusions}

Based on the analysis of research, the conclusion can be concluded that the metaphorical thinking abilities through STEM-CS learning are better than STEM learning and another learning model. STEM-CS learning becomes innovative learning that can be applied to optimize students' metaphorical thinking in the industrial revolution era 4.0.

The STEM-CS learning method used in the classroom is effective and capable of improving students' metaphorical thinking skills. Students are more engaged in lectures when they are confronted with real-world issues and are actively involved in resolving them. Additionally, students can use computer science to improve their skills in the STEM innovation stage. 
Additionally, students can investigate the causes of problems during the STEM-CS new idea step. Students are able to formulate real and significant problems in the field of mathematics and then propose solutions to these problems during this step. Students are able to collaborate with members of their respective groups to solve problems. Additionally, students are able to express their opinions in front of the class and argue in defense of their positions. This research can be expanded upon using STEM-CS models with a range of cognitive abilities. Due to the sample size being limited to secondary school students aged eleven to thirteen, there is a need to develop alternative forms of the STEM-CS for primary school students and high school students.

\section{Acknowledgments}

The highest gratitude is directed to the Research and Community Service Department (LP2M) of the Universitas Islam Negeri Raden Intan Lampung, Indonesia for the research funding.

Received: September 29, 2021

Accepted: January 14, 2022

Published: January 30, 2022

Farida, F. et al (2022). STEM approach and computer science impact the metaphorical thinking of Indonesian students'. RED. Revista Educación a Distancia, 22(69). http://dx.doi.org/10.6018/red.493721

\section{Funding}

The authors received funding from the Universitas Islam Negeri Raden Intan Lampung Fund. Grant number: B.1287/Un.16/R/TL.00/06/2019

\section{References}

Abdurrahman, A., Nurulsari, N., Maulina, H., \& Ariyani, F. (2019). Design and Validation of Inquiry-based STEM Learning Strategy as a Powerful Alternative Solution to Facilitate Gift Students Facing 21st Century Challenging. Journal for the Education of Gifted Young Scientists, 7(1), 33-56.

Abdurrahman, A., Setyaningsih, C. A., \& JALMO, T. (2019). Implementating Multiple Representation-Based Worksheet to Develop Critical Thinking Skills. Journal of Turkish Science Education, 16(1), 138-155.

Andari, T., Lusiana, R., \& Suherman, S. (2020). Teaching Material Topology: Development in Metacognitive Ability Tri Andari, Restu Lusiana and Suherman. Journal of Physics: Conference Series, 1467, 012021.

Barakabitze, A. A., William-Andey Lazaro, A., Ainea, N., Mkwizu, M. H., Maziku, H., Matofali, A. X., Iddi, A., \& Sanga, C. (2019). Transforming African Education Systems in Science, Technology, Engineering, and Mathematics (STEM) Using ICTs: Challenges and Opportunities. Education Research International, 2019. 
Barr, V., \& Stephenson, C. (2011). Bringing computational thinking to K-12: What is Involved and what is the role of the computer science education community? Acm Inroads, 2(1), 48-54.

Becker, K., \& Park, K. (2011). Effects of integrative approaches among science , technology, engineering, and mathematics ( STEM ) subjects on students ' learning: A preliminary meta-analysis. Journal of STEM Education, 12(5), 23-37.

Bell, D., Wooff, D., McLain, M., \& Morrison-Love, D. (2017). Analysing design and technology as an educational construct: An investigation into its curriculum position and pedagogical identity. The Curriculum Journal, 28(4), 539-558.

Bobrova, T. O., Ryabko, O. P., Vishnyakova, E. A., Sviontkovskaya, S. V., \& Ostrovskiy, V. I. (2020). The Cognitive Aspect of the Image Building of the Organization in the Framework of Economic Media Text. In Growth Poles of the Global Economy: Emergence, Changes and Future Perspectives (pp. 1017-1028). Springer.

Borrego, M., \& Henderson, C. (2014). Increasing the use of evidence-based teaching in STEM higher education: A comparison of eight change strategies. Journal of Engineering Education, 103(2), 220-252.

Çalisici, H., \& Sümen, Ö. Ö. (2018). Metaphorical Perceptions of Prospective Teachers for STEM Education. Universal Journal of Educational Research, 6(5), 871-880.

Canning, E. A., Muenks, K., Green, D. J., \& Murphy, M. C. (2019). STEM faculty who believe ability is fixed have larger racial achievement gaps and inspire less student motivation in their classes. Science Advances, 5(2), eaau4734.

Cassel, D., \& Vincent, D. (2011). Metaphors reveal preservice elementary teachers' views of mathematics and science teaching. School Science and Mathematics, 111(7), 319-324.

Castek, J., \& Beach, R. (2013). Using apps to support disciplinary literacy and science learning. Journal of Adolescent \& Adult Literacy, 56(7), 554-564.

Chang, L. P. L., \& Jonathan, L. Y. (2019). The Role of Scientific Terminology and Metaphors in Management Education. European Journal of Social Science Education and Research, 6(1), 33-43.

Chung, C. C. J., Cartwright, C., \& Chung, C. (2014). Robot music camp 2013: An experiment to promote STEM and computer science. 2014 IEEE Integrated STEM Education Conference, 1-7.

Dare, E. A., Ellis, J. A., \& Roehrig, G. H. (2018). Understanding science teachers' implementations of integrated STEM curricular units through a phenomenological multiple case study. International Journal of STEM Education, 5(1), 4.

de Barros, D. P., Primi, R., Miguel, F. K., Almeida, L. S., \& Oliveira, E. P. (2010). Metaphor creation: A measure of creativity or intelligence? European Journal of Education and Psychology, 3(1), 103-115.

Deitrick, E., Shapiro, R. B., Ahrens, M. P., Fiebrink, R., Lehrman, P. D., \& Farooq, S. (2015). Using distributed cognition theory to analyze collaborative computer science learning. Proceedings of the Eleventh Annual International Conference on International Computing Education Research, 51-60.

Drew, S. V. (2012). Open up the ceiling on the Common Core State Standards: Preparing students for 21st-century literacy-Now. Journal of Adolescent \& Adult Literacy, $56(4), 321-330$.

D'silva, J. L. (2007). Determinants of actual usage of computer among Mathematics, Science and English language teachers in secondary schools in Selangor, Malaysia. UPM, Kuala Lumpur. 
Duarte, E. F., \& Baranauskas, M. C. C. (2018). Interart: Learning human-computer interaction through the making of interactive art. International Conference on HumanComputer Interaction, 35-54.

Dumitru, D. (2019). Creating meaning. The importance of Arts, Humanities and Culture for critical thinking development. Studies in Higher Education, 44(5), 870-879.

Featherstone, M. (2020). Stiegler's ecological thought: The politics of knowledge in the anthropocene. Educational Philosophy and Theory, 52(4), 409-419.

Fitriani, D., Kaniawati, I., \& Suwarma, I. R. (2017). Pengaruh Pembelajaran Berbasis STEM (Science, Technology, Engineering, And Mathematics) Pada Konsep Tekanan Hidrostatis Terhadap Causal Reasoning Siswa SMP. Prosiding Seminar Nasional Fisika, 6, 47-52.

Gibbs Jr, R. W., Lima, P. L. C., \& Francozo, E. (2004). Metaphor is grounded in embodied experience. Journal of Pragmatics, 36(7), 1189-1210.

Goodway, J. D., Ozmun, J. C., \& Gallahue, D. L. (2019). Understanding motor development: Infants, children, adolescents, adults. Jones \& Bartlett Learning.

Greca Dufranc, I. M., García Terceño, E., Fridberg, M., Cronquist, B., \& Redfors, A. (2020). Robotics and Early-years STEM Education: The botSTEM Framework and Activities. European Journal of STEM Education, 1, 1-13.

Hartinah, S., Suherman, S., Syazali, M., Efendi, H., Junaidi, R., Jermsittiparsert, K., \& Umam, R. (2019). Probing-Prompting Based On Ethnomathematics Learning Model: The Effect On Mathematical Communication Skill. Journal for the Education of Gifted Young Scientists, 7(4), 799-814.

Hashim, H., Ali, M. N., \& Shamsudin, M. A. (2017). Infusing High Order Thinking Skills (HOTs) through Thinking Based Learning (TBL) during ECA to enhance students interest in STEM. International Journal of Academic Research in Business and Social Sciences, 7(11), 1191-1199.

Helmi, S. A., Mohd-Yusof, K., \& Hisjam, M. (2019). Enhancing the implementation of science, technology, engineering and mathematics (STEM) education in the 21st century: A simple and systematic guide. AIP Conference Proceedings, 2097(1), 020001 .

Hendriana, H. (2012). Pembelajaran matematika humanis dengan metaphorical thinking untuk meningkatkan kepercayaan diri siswa. Infinity Journal, 1(1), 90-103.

Hendriana, H., Hidayat, W., \& Ristiana, M. G. (2018). Student teachers' mathematical questioning and courage in metaphorical thinking learning. Journal of Physics: Conference Series, 948(1), 012019.

Hendriana, H., Rohaeti, E. E., \& Hidayat, W. (2017). Metaphorical Thinking Learning and Junior High School Teachers' Mathematical Questioning Ability. Journal on Mathematics Education, 8(1), 55-64.

Hernandez, P. R., Bodin, R., Elliott, J. W., Ibrahim, B., Rambo-Hernandez, K. E., Chen, T. W., \& de Miranda, M. A. (2014). Connecting the STEM dots: Measuring the effect of an integrated engineering design intervention. International Journal of Technology and Design Education, 24(1), 107-120.

Hobbs, L., Clark, J. C., \& Plant, B. (2018). Successful students-STEM program: Teacher learning through a multifaceted vision for STEM education. In STEM education in the junior secondary (pp. 133-168). Springer.

Huda, S., Komarudin, K., Suherman, S., Syazali, M., \& Umam, R. (2020). The Effectiveness of Al-Qurun Teaching Model (ATM) Viewed from Gender Differences: The Impact on Mathematical Problem-Solving Ability. Journal of Physics: Conference Series, 1467, 012001. 
Huda, S., Rinaldi, A., Suherman, S., Sugiharta, I., Astuti, D. W., Fatimah, O., \& Prasetiyo, A. E. (2019). Understanding of Mathematical Concepts in the Linear Equation with Two Variables: Impact of E-Learning and Blended Learning Using Google Classroom. Al-Jabar: Jurnal Pendidikan Matematika, 10(2), 261-270.

Ibáñez, M.-B., \& Delgado-Kloos, C. (2018). Augmented reality for STEM learning: A systematic review. Computers \& Education, 123, 109-123.

İdin, Ş. (2019). The metaphors of Turkish, Bulgarian and Romanian students on STEM disciplines. International Journal of Curriculum and Instruction, 11(2), 147-162.

Ismayani, A. (2016). Pengaruh Penerapan STEM Project- Based Learning Terhadap Kreativitas Matematis Siswa SMK. Indonesian Digital Journal of Mathematics and Education, 3(4), 264-272.

Jaccard, J., \& Jacoby, J. (2019). Theory construction and model-building skills: A practical guide for social scientists. Guilford Publications.

Kang, N.-H. (2019). A review of the effect of integrated STEM or STEAM (science, technology, engineering, arts, and mathematics) education in South Korea. AsiaPacific Science Education, 5(1), 6.

Kashdan, T. B., Stiksma, M. C., Disabato, D. J., McKnight, P. E., Bekier, J., Kaji, J., \& Lazarus, R. (2018). The five-dimensional curiosity scale: Capturing the bandwidth of curiosity and identifying four unique subgroups of curious people. Journal of Research in Personality, 73, 130-149.

Lakoff, G. (2014). Mapping the brain's metaphor circuitry: Metaphorical thought in everyday reason. Frontiers in Human Neuroscience, 8, 958.

Landau, M. J. (2016). Conceptual metaphor in social psychology: The poetics of everyday life. Psychology Press.

Laurens, T., Batlolona, F. A., Batlolona, J. R., \& Leasa, M. (2017). How does realistic mathematics education (RME) improve students' mathematics cognitive achievement? Eurasia Journal of Mathematics, Science and Technology Education, 14(2), 569-578.

Leikin, R. (2020). Giftedness and high ability in mathematics. Encyclopedia of Mathematics Education, 315-325.

Mayasari, T., Kadarohman, A., Rusdiana, D., \& Kaniawati, I. (2016). Exploration of student's creativity by integrating STEM knowledge into creative products. AIP Conference Proceedings, 1708(1), 080005.

McAuliffe, M. (2016). The potential benefits of divergent thinking and metacognitive skills in STEAM learning: A discussion paper. International Journal of Innovation, Creativity and Change, 2(3), 71-82.

Meerbaum-Salant, O., Armoni, M., \& Ben-Ari, M. (2013). Learning computer science concepts with scratch. Computer Science Education, 23(3), 239-264.

Meyrick, K. M. (2011). How STEM education improves student learning. Meridian K12 School Computer Technologies Journal, 14(1), 1-6.

Morgan, K., Barker, B., Nugent, G., \& Grandgenett, N. (2019). Educational Robotics as a Tool for Youth Leadership Development and STEM Engagement. In STEM Education 2.0 (pp. 248-275). Brill Sense.

Nilsen, P. (2020). Making sense of implementation theories, models, and frameworks. In Implementation Science 3.0 (pp. 53-79). Springer.

Ortiz, A. M., Bos, B., \& Smith, S. (2015). The power of educational robotics as an integrated STEM learning experience in teacher preparation programs. Journal of College Science Teaching, 44(5), 42-47. 
Park, M.-H., Dimitrov, D. M., Patterson, L. G., \& Park, D.-Y. (2017). Early childhood teachers' beliefs about readiness for teaching science, technology, engineering, and mathematics. Journal of Early Childhood Research, 15(3), 275-291.

Pellas, N., Kazanidis, I., Konstantinou, N., \& Georgiou, G. (2017). Exploring the educational potential of three-dimensional multi-user virtual worlds for STEM education: A mixed-method systematic literature review. Education and Information Technologies, 22(5), 2235-2279.

Peterson, B., \& Hipple, B. T. (2020). Formative Assessment in Hands-On STEM Education. In Handbook of Research on Formative Assessment in Pre-K Through Elementary Classrooms (pp. 165-193). IGI Global.

Pradubthong, N., Petsangsri, S., \& Pimdee, P. (2018). The Effects of the SPACE Learning Model on Learning Achievement and Innovation \& Learning Skills in Higher Education. Mediterranean Journal of Social Sciences, 9(4), 187-199.

Rany, W., Suherman, S., Anggoro, B. S., Negara, H. S., Yuliani, M. D., \& Utami, T. N. (2020). Understanding Mathematical Concept: The Effect Of Savi Learning Model With Probing-Prompting Techniques Viewed From Self-Concept. Journal of Physics: Conference Series, 1467, 012060.

Reeder, S., Utley, J., \& Cassel, D. (2009). Using metaphors as a tool for examining preservice elementary teachers' beliefs about mathematics teaching and learning. School Science and Mathematics, 109(5), 290-297.

Ritz, J. M., \& Fan, S.-C. (2015). STEM and technology education: International state-ofthe-art. International Journal of Technology and Design Education, 25(4), 429-451.

Ruthven, K., Hennessy, S., \& Brindley, S. (2004). Teacher representations of the successful use of computer-based tools and resources in secondary-school English, Mathematics and Science. Teaching and Teacher Education, 20(3), 259-275.

Sagala, R., Umam, R., Thahir, A., Saregar, A., \& Wardani, I. (2019). The effectiveness of STEM-Based on gender differences: The impact of physics concept understanding. European Journal of Educational Research, 8(3), 753-761.

Saragih, A., Silalahi, A., Sagala, S., Harahap, M., \& Saragih, A. H. (2016). METAPHORICAL THINKING AS A RESOURCE FOR IDEA ENGINEERING ENHANCEMENT.

Sari, F. K., Farida, F., \& Syazali, M. (2016). Pengembangan Media Pembelajaran (Modul) berbantuan Geogebra Pokok Bahasan Turunan. Al-Jabar: Jurnal Pendidikan Matematika, 7(2), 135-152.

Saxton, E., Burns, R., Holveck, S., Kelley, S., Prince, D., Rigelman, N., \& Skinner, E. A. (2014). A common measurement system for K-12 STEM education: Adopting an educational evaluation methodology that elevates theoretical foundations and systems thinking. Studies in Educational Evaluation, 40, 18-35.

Sengupta, P., Kinnebrew, J. S., Basu, S., Biswas, G., \& Clark, D. (2013). Integrating computational thinking with K-12 science education using agent-based computation: A theoretical framework. Education and Information Technologies, 18(2), 351-380.

Setiani, C., \& Waluya, S. B. (2018). Analysis of mathematical literacy ability based on self-efficacy in model eliciting activities using metaphorical thinking approach. Journal of Physics: Conference Series, 983(1), 012139.

Siew, N. M., Amir, N., \& Chong, C. L. (2015). The perceptions of pre-service and inservice teachers regarding a project-based STEM approach to teaching science. SpringerPlus, 4(1), 8.

Silvia, P. J., \& Beaty, R. E. (2012). Making creative metaphors: The importance of fluid intelligence for creative thought. Intelligence, 40(4), 343-351. 
Singh, P., Teoh, S. H., Cheong, T. H., Rasid, N. S. M., Kor, L. K., \& Nasir, N. A. M. (2018). The use of problem-solving heuristics approach in enhancing STEM students development of mathematical thinking. International Electronic Journal of Mathematics Education, 13(3), 289-303.

Skovsmose, O. (2020). Critical mathematics education. Springer.

Stoet, G., \& Geary, D. C. (2018). The gender-equality paradox in science, technology, engineering, and mathematics education. Psychological Science, 29(4), 581-593.

Suherman, S. (2018). Ethnomathematics: Eksploration of Traditional Crafts Tapis Lampung as Ilustration of Science, Technology, Engineering, and Mathematics (STEM). Eduma: Mathematics Education Learning and Teaching, 7(2), 21-30.

Suherman, S., Prananda, M. R., Proboningrum, D. I., Pratama, E. R., Laksono, P., \& Amiruddin, A. (2020). Improving Higher Order Thinking Skills (HOTS) with Project Based Learning (PjBL) Model Assisted by Geogebra. Journal of Physics: Conference Series, 1467, 012027.

Suherman, S., Vidákovich, T., \& Komarudin, K. (2021). STEM-E: Fostering mathematical creative thinking ability in the 21st Century. Journal of Physics: Conference Series, 1882(1), 012164. https://doi.org/10.1088/17426596/1882/1/012164

Supriadi, N., Farida, F., \& Kurniawati, N. (2019). Developing Student Worksheet Assisted with Geogebra on Derivative Materials. Journal of Physics: Conference Series, 1155(1), 012096.

Surya, E., \& Putri, F. A. (2017). Improving Mathematical Problem-Solving Ability and Self-Confidence of High School Students through Contextual Learning Model. Journal on Mathematics Education, 8(1), 85-94.

Suwarma, I. R., Astuti, P., \& Endah, E. N. (2015). Baloon Powered Car sebagai Media Pembelajaran IPA Berbasis STEM (Science, Thechnology, Engineering, and Mathematics). Proceed Simposium Nasional Inovasi Dan Pembelajaran Sains 2015.

Syukri, M., Lilia, H., \& Subahan, M. M. T. (2013). Pendidikan STEM dalam Entrepreneurial Science Thinking 'ESciT': Satu Perkongsian Pengalaman dari UKM untuk Aceh. Aceh Development International Conference, 105-112.

Tambunan, H. (2018). Impact of heuristic strategy on students' mathematics ability in high order thinking. International Electronic Journal of Mathematics Education, 13(3), 321-328.

Tati, T., Firman, H., \& Riandi, R. (2017). The Effect of STEM Learning through the Project of Designing Boat Model toward Student STEM Literacy. International Conference on Mathematics and Science Education (ICMScE), 1-8.

Trevallion, D. (2018). The changing professional identity of pre-service technology education students. International Journal of Innovation, Creativity and Change, 4(1), $1-15$.

Trilling, B., \& Fadel, C. (2009). 21 st century skills: Learning for life in our times. John Wiley \& Sons.

Ulfah, U., Prabawanto, S., \& Jupri, A. (2017). Students' mathematical creative thinking through problem posing learning. Journal of Physics: Conference Series, 895(1), 012097.

Vakil, S. (2018). Ethics, identity, and political vision: Toward a justice-centered approach to equity in computer science education. Harvard Educational Review, 88(1), 26-52.

Vale, I., Pimentel, T., \& Barbosa, A. (2018). The power of seeing in problem solving and creativity: An issue under discussion. In Broadening the Scope of Research on Mathematical Problem Solving (pp. 243-272). Springer. 
Vlasis, K. (2019). Paths of Friction: Intoning Societies, Identity, and Nature in 21stCentury Iceland. MUSICultures, 46(2), 62-XVI.

Vongkulluksn, V. W., Matewos, A. M., Sinatra, G. M., \& Marsh, J. A. (2018). Motivational factors in makerspaces: A mixed methods study of elementary school students' situational interest, self-efficacy, and achievement emotions. International Journal of STEM Education, 5(1), 43.

Wagiran, W., Pardjono, P., Suyanto, W., Sofyan, H., Soenarto, S., \& Yudantoko, A. (2019). Competencies of future vocational teachers: Perspective of in-service teachers and educational experts. Jurnal Cakrawala Pendidikan, 38(2), 387-397.

Woo, Y. L., Mokhtar, M., Komoo, I., \& Azman, N. (2012). Education for sustainable development: A review of characteristics of sustainability curriculum. OIDA International Journal of Sustainable Development, 3(8), 33-44.

Yasin, M., Huda, S., Komarudin, S., Suherman, S., Septiana, R., \& Palupi, E. K. (2020). Mathematical Critical Thinking Ability: The Effect of Scramble Learning Model assisted by Prezi in Islamic School. Journal of Physics: Conference Series, 1467, 012007.

Yin, C., Ogata, H., \& Yano, Y. (2007). Participatory simulation framework to support learning computer science. International Journal of Mobile Learning and Organisation, 1(3), 288-304.

Yu, Y.-C., Chang, S.-H., \& Yu, L.-C. (2016). An academic trend in STEM education from bibliometric and co-citation method. International Journal of Information and Education Technology, 6(2), 113. 